\title{
Studies on Cell Wall of Alkalophilic Bacillus
}

\author{
Yoko IKURA and Koki HorIKOSHI \\ The Institute of Physical and Chemical Research, \\ Wako-shi, Saitama 351, Japan
}

Received June 11, 1982

\begin{abstract}
Cell walls of alkalophilic Bacillus No. C-125 and No. A-59 which grew in different pH conditions were prepared and analyzed. In the walls from cells grown at $\mathrm{pH} 10.3$ ( $\mathrm{pH}$ 10.3-cell wall) and the walls from cells grown at $\mathrm{pH} 7.5$ ( $\mathrm{pH} 7.5$-cell wall) of the alkalophilic bacilli, the contents of neutral sugar and phosphorus were low as compared with those of Bacillus subtilis 6160 , while uronic acid and amino acids were abundant. The uronic acid content of the $\mathrm{pH}$ 10.3-cell walls was higher than that of the $\mathrm{pH} 7.5$-cell walls in both strains. The insoluble fraction (peptidoglycan) of cell walls of Bacillus No. C-125 consisted of muramic acid, glutamic acid, alanine, diaminopimelic acid and glucosamine as in neutrophilic bacilli. In the TCA soluble fraction of $\mathrm{pH}$ 10.3-cell walls of Bacillus No. C-125, uronic acid was a polymer of glucuronic acid containing a small amount of hexosamine, and $2 / 3$ of the ninhydrin positive material was glutamic acid which was derived mainly from poly $\gamma$-L-glutamic acid.
\end{abstract}

There is no report on the cell walls of alkalophilic Bacillus strains which can grow in an extremely high $\mathrm{pH}$ environment. The cell walls which are on the outer side of the cell and come directly into contact with the alkaline environment might be different from those of neutrophilic bacteria. High $\mathrm{pH}$ values of media may change the components and structure of the cell wall. Alkalophilic Bacillus strains can grow in $\mathrm{pH} 10.3$ media, while $B$. subtilis 6160 could not grow in these media and was unstable at $\mathrm{pH} 10.3$ (turbidity of intact cells of B. subtilis 6160 decreased to $89 \%$ at $37^{\circ} \mathrm{C}$ for $1 \mathrm{hr}$, unpublished observation). Therefore, it is possible that there is an alkaline-tolerance mechanism in the cell walls. In this work, we analyzed the cell walls of two alkalophilic Bacillus strains, No. C-125 and No. A-59, which grew under highly alkaline and near neutral $\mathrm{pH}$ conditions.

\section{MATERIALS AND METHODS}

Microorganisms. The following microorganisms which were isolated in our labolatory were used: alkalophilic Bacillus No. C-125 which produces an inducible $\beta$-galactosidase $^{1)}$ and alkalophilic Bacillus No. A-59 which is an alkaline amylase producer. ${ }^{2)}$
Growth conditions. The medium contained $15 \mathrm{~g}$ soluble starch; $10 \mathrm{~g}$ polypeptone; $2.5 \mathrm{~g}$ yeast extract; $1 \mathrm{~g} \mathrm{~K}_{2} \mathrm{HPO}_{4}$; $0.2 \mathrm{~g} \mathrm{MgSO}_{4} \cdot 7 \mathrm{H}_{2} \mathrm{O} ; 10 \mathrm{~g} \mathrm{Na}_{2} \mathrm{CO}_{3}$ (for an alkaline medium, $\mathrm{pH} 10.3$ ) or $11.7 \mathrm{~g} \mathrm{NaCl}$ (for an near neutral medium, the $\mathrm{pH}$ was adjusted to 7.5 with $\mathrm{NaOH}$ ); and $1,000 \mathrm{ml}$ of water. $\mathrm{Na}_{2} \mathrm{CO}_{3}$ or $\mathrm{NaCl}$ was sterilized separately. The microorganisms were cultured at $37^{\circ} \mathrm{C}$ for $16 \mathrm{hr}$ and collected by centrifugation at $6,000 \times g$ for $10 \mathrm{~min}$ and washed twice with $0.85 \% \mathrm{NaCl}$ solution containing $10 \mathrm{~mm}$ $\mathrm{MgCl}_{2}$.

Materials. The reagents were obtained from the following sources; DNase from Boehringer Mannheim GmbH. Co., Ltd., RNase and L-glutamate dehydrogenase from Sigma Chemical Co., Ltd., and pronase from Kaken Kagaku Co., Ltd., Tokyo.

Isolation of cell walls. The harvested cells were suspended into distilled water. To the cell suspension, sodium dodecylsulfate was added to a final concentration of $2.5 \%$. The mixture was incubated at $52^{\circ} \mathrm{C}$ for $18 \mathrm{hr}$ with continuous shaking and then centrifuged at $10,000 \times g$ for $10 \mathrm{~min}$. The precipitate was washed twice with distilled water and disrupted by grinding with three volumes of quartz sand. The disrupted cells were centrifuged at $6,000 \times g$ for $5 \mathrm{~min}$ to remove unbroken cells and the supernatant fluid was centrifuged at $12,000 \times g$ for $10 \mathrm{~min}$ to obtain the cell walls. The cell wall fraction was washed 7 times with distilled water and suspended in $5 \mathrm{mM} \mathrm{NaCl}$ solution containing $2 \mathrm{mM} \mathrm{MgCl}_{2}$. DNase (Grade II, $20 \mu \mathrm{g} / \mathrm{ml})$, RNase $(50 \sim 75 \mathrm{Kunitz}$ units per $\mathrm{mg}$ protein, $10 \mu \mathrm{g} / \mathrm{ml}$ ) and a few drops of toluene were added to the 
suspension. The mixture was incubated at $37^{\circ} \mathrm{C}$ for $5 \mathrm{hr}$, then pronase $(15,000$ p.u.k. $/ \mathrm{g}, 50 \mu \mathrm{g} / \mathrm{ml})$ was added and the mixture incubated for $16 \mathrm{hr}$ with shaking. The digested fraction was centrifuged at $15,000 \times g$ for $10 \mathrm{~min}$ and washed with 5 times with distilled water and then used as the cell walls.

Extraction with trichloroacetic acid (TCA). To the cell wall suspension, an equal volume of $20 \%$ TCA was added and the mixture incubated at $37^{\circ} \mathrm{C}$ for $16 \mathrm{hr}$. This extraction was repeated 4 times which was enough to extract almost all phosphate and soluble sugars. The extracts were combined and TCA was removed with ether, then the solution was concentrated in vacuo and used as the TCA soluble fraction of cell walls. The insoluble fraction was washed with distilled water, dried in vacuo and used as the TCA insoluble fraction.

Analytical methods. Uronic acid and neutral sugar were measured by the carbazol method ${ }^{3)}$ and the phenol sulfuric acid method ${ }^{4)}$ after separation by the method of White et $a l^{5)}$ As uronic acid was thermolabile on acid hydrolysis, various conditions were tested and hydrolysis with $2 \mathrm{~N} \mathrm{HCl}$ at $100^{\circ} \mathrm{C}$ for $30 \mathrm{~min}$ gave the best results. Total amino sugar was estimated by the Elson-Morgen method ${ }^{6)}$ after hydrolysis with $4 \mathrm{~N} \mathrm{HCl}$ for $16 \mathrm{hr}$ at $100^{\circ} \mathrm{C}$ and ninhydrin positive material was determined by the ninhydrin method of Yemm-Cocking ${ }^{7)}$ after hydrolysis with $6 \mathrm{~N} \mathrm{HCl}$ at $105^{\circ} \mathrm{C}$ for $18 \mathrm{hr}$. Individual amino acids and amino sugars were analyzed with an amino acid analyzer (JLC-6AH, Nihon Denshi Co., Ltd.). The content of L-glutamic acid was determined by the L-glutamate dehydrogenase method. ${ }^{8)}$

\section{RESULTS}

\section{Analysis of cell walls}

Cell walls of Bacillus No. C-125 and No. A-
59 grown at $\mathrm{pH} 7.5$ and $\mathrm{pH} 10.3$ and $B$. subtilis 6160 grown at $\mathrm{pH} 7.2$ were prepared and analyzed separately. As shown in Table I, there are several differences between the cell walls of the alkalophilic Bacillus strains and $B$. subtilis 6160 . In cell walls of the alkalophilic bacilli, neutral sugar and phosphorus contents were low and contents of uronic acid and ninhydrin positive material were high compared with those of B. subtilis 6160 . There are differences also between the cell walls of cells grown at different $\mathrm{pHs}$. The content of uronic acid of the $\mathrm{pH}$ 10.3-cell walls was higher than that of the $\mathrm{pH} 7.5$-cell walls. The neutral sugar content of the $\mathrm{pH}$ 10.3-cell walls was lower than that of the $\mathrm{pH}$ 7.5-cell walls. No remarkable difference was observed in amino acid and phosphorus contents.

\section{Constituents of TCA soluble and insoluble fractions}

The TCA soluble fraction amounted to $58.9 \%(\mathrm{w} / \mathrm{w})$ of the $\mathrm{pH} 7.5$-cell wall and $61.5 \%$ (w/w) of the $\mathrm{pH} 10.3$-cell wall of Bacillus No. $\mathrm{C}-125$. The contents of neutral sugar, uronic acid, ninhydrin positive material, phosphorus and amino sugar in the TCA soluble fraction were determined. As shown in Table II, only amino acids and amino sugar were detected in the TCA insoluble fraction (peptidoglycan) and essentially no remarkable difference was seen between the $\mathrm{pH}$ 7.5-cell wall and $\mathrm{pH}$ 10.3-

Table I. Composition of Cell Walls of Bacillus No. C-125, No. A-59 AND B. subtilis 6160

Cell walls were prepared and analyzed as described in the text. Uronic acid was measured as glucuronic acid, ninhydrin positive material as glutamic acid, neutral sugar as glucose and Elson-Morgen positive material as glucosamine. Results are expressed as $\mu \mathrm{mol}$ per $\mathrm{mg}$ cell wall. B. subtilis was cultured with the omission of $\mathrm{NaCl}$.

\begin{tabular}{|c|c|c|c|c|c|}
\hline & \multicolumn{5}{|c|}{ Cell wall } \\
\hline & Bacillus & $\mathrm{C}-125$ & \multicolumn{2}{|c|}{ Bacillus No. A-59 } & \multirow{2}{*}{$\frac{\text { B. subtilis } 6160}{\mathrm{pH} 7.2}$} \\
\hline & $\mathrm{pH} 7.5$ & $\mathrm{pH} 10.3$ & pH 7.5 & $\mathrm{pH} 10.3$ & \\
\hline Uronic acid & 0.41 & 0.67 & 0.39 & 0.57 & 0.20 \\
\hline Ninhydrin positive material & 3.64 & 3.23 & 3.21 & 3.14 & 1.62 \\
\hline Phosphorus & 0.16 & 0.14 & 0.17 & 0.13 & 1.23 \\
\hline Neutral sugar & 0.13 & 0.08 & 0.12 & 0.11 & 1.12 \\
\hline Elson-Morgen positive material & 0.51 & 0.40 & 0.37 & 0.31 & 0.30 \\
\hline
\end{tabular}


Table II. Analysis of TCA Soluble and Insoluble Fractions of Bacillus No. C-125 Cell Walls and TCA Soluble Fraction of Bacillus No. A-59 Cell Walls

Cell walls were extracted four times with $10 \%$ TCA and analyzed as described in the text. Results are expressed as $\mu \mathrm{mol}$ per mg cell wall.

\begin{tabular}{|c|c|c|c|c|c|c|}
\hline & \multicolumn{4}{|c|}{ TCA soluble } & \multirow{2}{*}{\multicolumn{2}{|c|}{$\frac{\text { TCA insoluble }}{\text { Bacillus No. C-125 }}$}} \\
\hline & \multicolumn{2}{|c|}{ Bacillus No. C-125 } & \multicolumn{2}{|c|}{ Bacillus No. A-59 } & & \\
\hline & pH 7.5 & pH 10.3 & $\mathrm{pH} 7.5$ & $\mathrm{pH} 10.3$ & $\mathrm{pH} 7.5$ & pH 10.3 \\
\hline Uronic acid & 0.39 & 0.64 & 0.37 & 0.52 & - & - \\
\hline Ninhydrin positive material & 0.87 & 0.88 & 0.75 & 0.81 & 2.76 & 2.37 \\
\hline Glutamic acid & 0.62 & 0.68 & 0.35 & 0.45 & 0.52 & 0.51 \\
\hline Aspartic acid & 0.02 & 0.01 & 0.18 & 0.21 & - & - \\
\hline Phosphorus & 0.15 & 0.14 & N.D. & N.D. & - & - \\
\hline Neutral sugar & 0.11 & 0.05 & N.D. & N.D. & - & - \\
\hline Elson-Morgen positive material & 0.09 & 0.06 & 0.09 & 0.03 & 0.37 & 0.31 \\
\hline
\end{tabular}

-, absent; N.D., not determined.

Table III. Amino Compounds of Cell Walls of Bacillus No. C-125

The method and hydrolysis conditions are described under Methods. Amide $\mathrm{NH}_{3}$ was less than $7 \%$ of the total amino compounds in each fraction.

\begin{tabular}{|c|c|c|c|c|}
\hline & \multicolumn{2}{|c|}{ TCA soluble } & \multicolumn{2}{|c|}{ TCA insoluble } \\
\hline & $\begin{array}{c}\mathrm{pH} 7.5-\text { Cell wall } \\
(\%)\end{array}$ & $\begin{array}{c}\mathrm{pH} 10.3-\mathrm{Cell} \text { wall } \\
(\%)\end{array}$ & $\begin{array}{c}\mathrm{pH} 7.5-\text { Cell wall } \\
(\%)\end{array}$ & $\begin{array}{c}\mathrm{pH} 10.3-\mathrm{Cell} \text { wall } \\
(\%)\end{array}$ \\
\hline Aspartic acid & 1.8 & 1.1 & - & - \\
\hline Muramic acid & - & - & 12.2 & 11.8 \\
\hline Glutamic acid & 67.8 & 77.0 & 19.0 & 21.6 \\
\hline Glycine & 4.1 & 2.6 & - & - \\
\hline Alanine & 12.7 & 11.1 & 31.3 & 27.4 \\
\hline Diaminopimelic acid & 1.5 & 1.1 & 17.9 & 18.4 \\
\hline Glucosamine & 2.5 & 1.8 & 13.7 & 12.2 \\
\hline Galactosamine & 4.6 & 3.3 & - & - \\
\hline Lysine & 5.1 & 2.1 & - & - \\
\hline
\end{tabular}

- , absent.

cell wall fractions. Large amounts of uronic acid and amino acids were detected in the TCA soluble fraction of both $\mathrm{pH} 7.5$-cell walls and $\mathrm{pH}$ 10.3-cell walls.

\section{Amino acids and amino sugars of TCA soluble and peptidoglycan fractions}

The TCA soluble fraction and TCA insoluble fraction of $\mathrm{pH} 7.5$-cell walls and $\mathrm{pH}$ 10.3-cell walls were hydrolyzed in $\mathrm{HCl}$ as described in Materials and Methods. As shown in Table III, no muramic acid was observed in the TCA soluble fraction and it is striking that $2 / 3$ of the ninhydrin positive material was glutamic acid in Bacillus No. C125. Muramic acid, glutamic acid, alanine, diaminopimelic acid and glucosamine were found in the TCA insoluble fraction. Although several differences were detected between the TCA insoluble fractions, peptidoglỳcans of $\mathrm{pH}$ 7.5-cell walls and $\mathrm{pH}$ 10.3-cell walls are essentially identical. In the TCA soluble fraction of Bacillus No. A-59, the total amount of acidic amino acids was about 70 to $80 \%$ of the 
ninhydrin positive material. Not only glutamic acid but also aspartic acid was observed in that fraction to a great extent (Table II). These data strongly suggest that such a high content of acidic compounds must be a characteristic of alkalophilic Bacillus strains. Therefore, further investigation was focused on the TCA soluble fraction.

\section{Properties of the TCA soluble fraction}

Fractionation of the TCA soluble fraction. The TCA soluble fraction of $\mathrm{pH}$ 10.3-cell walls of Bacillus No. C-125 was used. This fraction was viscous, slightly turbid and not adsorbed by ion exchangers such as DEAE-cellulose. For further studies, the TCA soluble fraction was partially hydrolyzed in $1 \mathrm{~N} \mathrm{HCl}$ at $100^{\circ} \mathrm{C}$ for $30 \mathrm{~min}$ and $\mathrm{HCl}$ was removed in vacuo. The hydrolyzate was loaded onto a Bio Rad AG-1 column (formate form) to separate low molecular weight compounds of uronic acid. The effluent was concentrated and fractionated by passing through a Sephadex G-25 column (Fig. 1). Fractions from No. 21 to No. 25 were combined and concentrated in vacuo. The concentrate was passed through a Dowex $50 \times 2$ column ( $\mathrm{H}$ form) and more than $90 \%$ was not adsorbed. The effluent was concentrated in vacuo. Only uronic acid, hexosamine and amino acids were detected, and the molar ratio of glucuronic acid, glucosamine and glutamic acid was calculated to be $1.0: 0.06: 1.06$. Other compounds such as phosphorus and

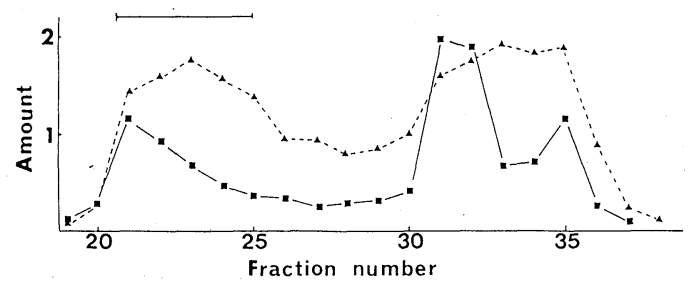

Fig. 1. Gel Filtration of Partial Hydrolyzate of TCA Soluble Fraction of pH 10.3-Cell Wall of Bacillus No. C125.

Partial hydrolyzate effluent (from Bio Rad AG-1, formate form) was loaded on a Sephadex G-25 column $(1.5 \times$ $100 \mathrm{~cm}$ ) and fractionated at $3 \mathrm{ml} /$ tube. The flow rate was $5 \mathrm{ml} / \mathrm{hr}$. $\square$, uronic acid; $\mathbf{\Delta}^{---\boldsymbol{\Delta}}$, amino acid after hydrolysis. neutral sugar were not detected. This fraction was a mixture of a glutamic acid-rich fraction and a uronic acid-rich fraction, because both fractions could be partially separated from each other by passage through a Sephadex G25 column again (Fig. 2).

Glutamic acid-rich fraction. No Biuret reaction was observed for the glutamic acid-rich fraction (fraction Nos. 17 and 18, glutamic acid : uronic acid $=2.6: 1.0$ ). This fraction was hydrolyzed in $6 \mathrm{~N} \mathrm{HCl}$ at $105^{\circ} \mathrm{C}$ for $18 \mathrm{hr}$. Total glutamic acid was determined with an amino acid analyzer and L-glutamic acid was measured enzymatically. $91.8 \%$ of the glutamic acid was the L form. Although this fraction has not yet been entirely purified, these analytical results indicate that the main component of the fraction is poly $\gamma$-L-glutamic acid.

Uronic acid-rich fraction. The uronic acidrich fraction (fraction Nos. 19 and 20, uronic acid : glutamic acid $=1.8: 1.0)$ was not hydrolyzed by hyaluronidase (endo type) or $\beta-1,4$ glucuronidase (exo type). As shown in Fig. 3, absorption spectra measured by the Dische method $^{10)}$ suggest that the fraction contains glucuronic acid. One mole of uronic acid as glucuronic acid consumed 0.89 mol of sodium periodate. No glycerol ${ }^{11)}$ was detected by so-

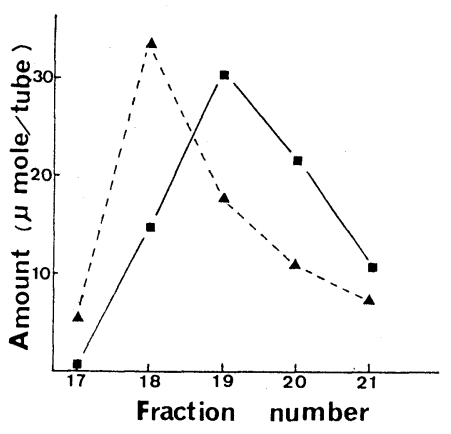

FIG. 2. Rechromatography of Partial Hydrolyzate on Sephadex G-25.

Fractions from No. 21 to 25 in Fig. 1 were loaded onto Dowex $50 \times 2(\mathrm{H})$ before rechromatography. The effluent from Dowex $50 \times 2(\mathrm{H})$ was concentrated and rechromatographed on a Sephadex G-25 column $(1.5 \times 90 \mathrm{~cm})$. The flow rate was $5 \mathrm{ml} / \mathrm{hr}$ and fractions of $3 \mathrm{ml} /$ tube were collected. $\mathbf{\square}-\mathbf{\square}$, uronic acid; $\boldsymbol{\Delta}--\boldsymbol{\Delta}$, amino acid after hydrolysis. 


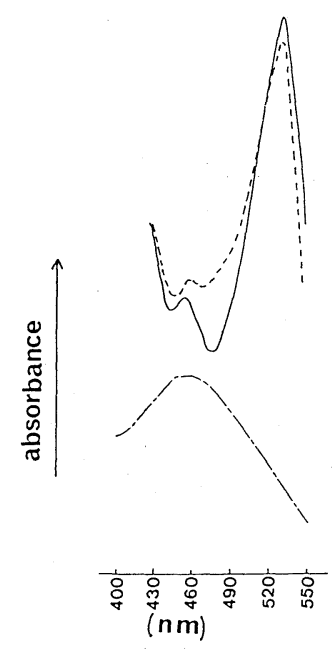

FIG. 3. Absorption Spectra of Hexuronic acids.

Spectra were measured by the method of Dische. ${ }^{10)}$ standard glucuronic acid; --..-, standard galacturonic acid; ---.--, uronic acid from cell walls of Bacillus No. C125 .

dium borohydride treatment following Smith degradation. These results suggest that the uronic acid-rich compound may be a polymer of glucuronic acid which has an $\alpha-1,4$ linkage, probably containing a small amount of hexosamine because Elson-Morgen positive material was detected in the fraction.

\section{DISCUSSION}

As investigation of the alkalophilicity of alkalophilic Bacillus strains, extensive work has been done mainly in our laboratory. Although several differences between alkalophilic and neutrophilic Bacillus strains were exhibited, none of them was crucial. The difference must be in the cell surface, because the cell surface is in direct contact with the high alkaline environment and plays a role in keeping the internal $\mathrm{pH}$ at neutrality. ${ }^{12)}$ Though the protoplasts of Bacillus No. C-125 were considerably stable compared with those of $B$. subtilis on addition of $10 \mathrm{~mm} \mathrm{MgCl}_{2}$ at $\mathrm{pH}$ 10.2 , turbidity of the protoplasts $\left(A_{610}\right)$ at room temperature after $20 \mathrm{~min}$ was decreased to $80 \%$ (unpublished result). Accordingly, it is suspected that the alkaline-tolerance mech- anism was partially in the cell membrane but mainly in the wall. At the beginning, we dealt with cell walls. Cell walls were prepared from cells grown at $\mathrm{pH} 7.5$ and 10.3 , because No. C125 and No. A-59 can grow well at these pHs. In order to determine the location and properties of these uronic acid and amino compounds, the cell wall was fractionated into two fractions, a TCA soluble fraction and a TCA insoluble fraction.

Uronic acid was detected only in the TCA soluble fraction and the content changed depending upon the extracellular $\mathrm{pH}$ conditions. A high $\mathrm{pH}$ culture medium gave a high content of uronic acid. Uronic acid detected in No. C-125 was glucuronic acid as detected in neutrophilic bacilli. The TCA soluble fraction in $B$. licheniformis ${ }^{13)}$ contains not only uronic acid but also hexosamine equally (teichuronic acid), while the hexosamine content of the TCA soluble fraction of alkalophilic bacilli was extremely low. Another interesting point is that the glutamic acid content is about $70 \%$ of total ninhydrin positive material in the TCA soluble fraction of Bacillus No. C-125, although $\mathrm{pH}$ dependency was not observed. Such a high content of acidic substances is one of the characteristic properties of alkalophilic Bacillus strains, bacause the cell wall of another alkalophilic Bacillus, No. A-59, also contains a large amount of glutamic acid and aspartic acid in addition to a large amount of uronic acid.

These acidic compounds of Bacillus No. C125 were studied further. Uronic acid-rich and glutamic acid-rich fractions were prepared by gel filtration from the TCA soluble fraction. The glutamic acid-rich fraction contained a poly $\gamma$-L-glutamic acid. Polyglutamic acid was reported as a capsule polymer in some neutrophilic bacilli, but there is no report of a large amount of polyglutamic acid in the TCA soluble fraction of cell walls. The uronic acidrich fraction is a polymer of glucuronic acid which may have an $\alpha-1,4$ linkage containing a small amount of hexosamine.

The composition of the TCA insoluble fraction (peptidoglycan) was not affected by the 
extracellular $\mathrm{pH}$ and it is essentially the same as those of neutrophilic bacilli. These results indicate that the extracellular $\mathrm{pH}$ had an influence on the structure of the TCA soluble materials of the cell wall, whereas the peptidoglycan structure was not changed. It was concluded that the cell walls of alkalophilic Bacillus No. C-125 consist of a usual type of peptidoglycan as in neutrophilic bacilli, and acidic polymers, poly- $\gamma$-L-glutamic acid and polyglucuronic acid, probably teichuronic acid. And the content of acidic polymers which lead to some chemical changes on the cell surface is affected by the external $\mathrm{pH}$. Therefore, it is assumed that alkalophilic Bacillus may acquire alkalophilicity by changing acidic compounds of the cell wall from teichoic acid to polymers of uronic acid and acidic amino acids.

\section{REFERENCES}

1) Y. Ikura and K. Horikoshi, Agric. Biol. Chem., 43, 85 (1979).

2) M. Yamamoto, Y. Tanaka and K. Horikoshi, Agric. Biol. Chem., 36, 1819 (1972).

3) Z. Dische, J. Biol. Chem., 167, 189 (1947).

4) M. Dubois, K. A. Gilles, J. K. Hamilton, P. A. Rebers and F. Smith, Anal. Chem., 28, 350 (1956).

5) P. J. White and C. Gilberg, Biochemistry, 16, 2428 (1977).

6) R. Belcher, A. J. Nutten and C. M. Sambrook, Analyst, 79, 201 (1954).

7) E. W. Yemm and E. C. Cocking, Analyst, 80, 209 (1955).

8) H. U. Bergmeyer, "Methods of Enzymatic Analysis," 2nd Ed., Academic Press, New York and London, 1974, p. 1704.

9) B. N. Ames, Methods in Enzymology, 8, 115 (1966).

10) Z. Dische, J. Biol. Chem., 171, 725 (1947).

11) A. Misaki, "Seikagaku Jikken Koza," Vol. IV, ed. by Nippon Kagakukaishi, Tokyo Kagaku Dojin, Co., 1976, p. 484.

12) A. A. Guffanti, R. Blanco and T. A. Krulwich, $J$. Biol. Chem., 254, 1033 (1979).

13) R. C. Hughes, Biochem. J., 96, 700 (1965). 